\title{
Analysis of Mathematics Learning Outcomes in Elementary School Students as Efforts to Implement HOTS-Based Learning
}

\author{
Sarnoko $^{1}$, Budiyono $^{2}$, Nunuk Suryani $^{3}$, Asrowi $^{4}$ \\ \{ sarnokopariman1980@ gmail.com ${ }^{1}$, budiyono@staff.uns.ac.id ${ }^{2}$, nunuksuryani@fkip.uns.ac.id ${ }^{3}$, \\ asrowi@staf.uns.ac.id $\left.{ }^{4}\right\}$
}

Doctoral Program in Educational Science, Sebelas Maret University, Indonesia ${ }^{1}$, Teacher Training and Education Faculty of Universitas SebelasMaret, Indonesia2,3,4

\begin{abstract}
This study aims to analyze the mathematics learning outcomes of elementary school students using Higher Order Thinking Skills (HOTS) -based learning. HOTS-based learning is expected to improve student competence, especially in higher-order thinking skills, namely the ability to think critically, creatively, and analytically. This research is preliminary data to determine student learning outcomes. This research was conducted in 5 elementary schools in 5 clusters located in Girimarto District. The study was conducted with a total of 106 students, with details of 53 male students and 53 female students. The results of the analysis show that the students' high-order thinking skills are still in the low category. This is evidenced by $46.86 \%$ of students mastering the critical thinking component, $37.50 \%$ of students mastering the creative thinking component, and only $30.82 \%$ of students mastering the analytical thinking component. The average of the three components is $37.61 \%$. This study recommends the application of the Problem Based Learning (PBL) learning model as an effort to improve mathematics learning outcomes of elementary school students. It is expected that students' higher-order thinking skills will be more honed so that they can become provisions in the future. PBL learning model is a learning model that can improve students' higher-order thinking skills. This learning model allows students to learn by doing and applying ideas obtained from available data or information.
\end{abstract}

Keywords: Higher Order Thinking Skills (HOTS), mathematics learning outcomes, Problem Based Learning (PBL)

\section{Introduction}

The Indonesian Ministry of Education and Culture has started implementing national standards for mathematics, namely the use of high-level reasoning / high-order thinking, or better known as Higher Order Thinking Skills (HOTS). In this case, the government hopes that by implementing HOTS-based learning, students can achieve various competencies. Competencies to be achieved include critical thinking, creative and innovative thinking, communication skills, collaboration skills, and confidence [1]. Learning thinking skills must be used as a part of the applied curriculum if students are to be able to solve each problem individually, cooperatively and creatively. In addition, teachers must also be fluent in mastering the techniques needed to teach on a high-level thinking basis. A literature review shows that 
teachers are generally faced with the problem of how to prepare and teach higher-order thinking skills in educational technology and design. Some components of higher-order thinking are the use of concepts, conclusions, visualization, and schemes [2].

Learning is closely related to three aspects, namely cognitive, affective, and psychomotor. Within each domain there are several levels of learning that progress from fundamental learning to more complex and deeper learning [3]. HOTS-based learning is very supportive in improving these three aspects. HOTS-based learning also requires students to be active in teaching and learning activities. The phenomenon that is still widely encountered is that the material in mathematics is only limited to the transfer of knowledge from teachers to students. This is what often results in students lacking in higher order thinking activities. For example, applying formulas in solving math problems. Students tend to only know the formula and then apply it in solving problems, without knowing how the formula can be created. When students do not know the concept, it will cause them difficulties if they are faced with the same questions but have been given variations. Therefore, the teacher's role is very important in HOTS-based learning activities. One learning model that can improve students' high-level thinking skills is a problembased learning model or what is commonly called Problem Based Learning (PBL). This learning model allows students to learn by doing and implementing ideas. If this model is applied in schools, it will improve students' higher order thinking skills. This results in the achievement of learning objectives so that the quality of the school increases.

Problem Based Learning (PBL) deserves to be considered as one of the 21st century learning models that can place HOTS improvements as the goals and needs of students. PBL is a pedagogical approach that provides opportunities to achieve learning objectives. The main key of PBL is that learning must be done in a real way [4].

\subsection{Learning outcomes}

Learning outcomes have an important role for meaningful education. Learning outcomes are very important because they can serve as a diagnosis and can improve the quality of the teaching and learning process. Emphasis on student learning outcomes has become more important in many countries in recent years. There has been increasing interest in developing comparative measures of learning outcomes aimed at dealing with trends in higher education, paradigm shifts and challenges [5]. There are five types of learning outcomes that have been widely accepted. These categories are intellectual skills (procedural knowledge), verbal information (declarative knowledge), cognitive strategies (executive control processes), motor skills, and attitudes [6]. Learning outcomes are seen as something students can do now, which could not be done before.

There are six areas of measurable learning outcomes, namely: critical thinking, communication, career and teamwork, responsibility, understanding, and development [7]. Student learning outcomes provide a direct measure of a student's academic ability and are considered a powerful tool for evaluating the impact of learning at school on students. Satisfactory student learning outcomes also have an impact on schools and institutions engaged in education. It can also influence policy makers. Even though it has an impact on various areas of life, students still think that the learning outcomes they get do not have any influence on them. So that students are less motivated to improve learning outcomes. Satisfactory learning outcomes are also influenced by several factors, namely student ability, learning motivation, the role of teachers, facilities and infrastructure and others [8].

Evaluation of individual learning outcomes can help a school or institution improve its performance, promote learning opportunities, and improve the school's long-term goals. 
Comparison of student learning outcomes through learning activities is very important to understand whether the programs implemented by schools are appropriate and can improve school quality [9]. Competence and student learning outcomes aim to improve school performance and students themselves. Learning that is carried out in order to improve student learning outcomes needs special attention, namely by sorting specific and general lessons as an integrated approach to knowledge, understanding, skills, abilities and attitudes.

\subsection{Higher Order Thinking Skills (HOTS) based learning}

It is not enough for students to only master the fields of reading, writing and counting, but students also need to develop higher-order thinking skills such as critical reading / literacy, critical computing, and cross-curricular competencies. HOTS is divided into two contexts, namely the skills used to solve problems and make decisions in everyday life [10].

HOTS is a skill to transfer or apply what students have, then the information is learned into a new context. HOTS acts as critical thinking and problem solving skills. In the context of problem solving, HOTS involves analyzing information to determine problems, evaluate problems and create new workable solutions. HOTS can be taught and can be learned. HOTS development is not only to develop students' cognitive but also to develop individuals to become versatile. HOTS is a skill that allows students to find solutions for real life or certain professions. The problem in question is one that cannot be solved using only memorization solutions but a combination of different skills, so it is referred to as logical analytical reasoning, reflective thinking and evaluating creative skills, and developing creative problem solving strategies. Problem solving is important for developing critical thinking, creative thinking, and effective communication [4].

Critical thinking skills. Critical thinking skills are a thinking process that aims to make rational decisions that are directed to decide what to believe or do [11]. Critical thinking is a process of knowledge and skills deployed to solve problems that arise, make decisions, analyze all assumptions that arise and carry out investigations based on the data and information obtained so that they can produce a conclusion. Critical thinking is the term most people associate with higher order thinking skills (HOTS). Critical thinking is wise thinking. This begins with the hope that the wisdom received will be one of the valid views. Critical thinking involves an explicit comparison of possible explanations, theories, and models [12].

It should be noted that all disciplines such as mathematics, physics, chemistry, biology, geography, sociology, anthropology, history, philosophy, and so on, require critical thinking skills in their material. For example, in mathematics, it is not enough just to know and memorize the formulas but to do mathematical thinking. Likewise with science, not only material in books but also thinking scientifically. This shows the importance of critical thinking skills in various aspects of life [13].

Critical thinking is now widely seen as a basic competency, such as reading and writing, that needs to be taught. Studying critical thinking involves trying to change the way we think. To do this we need extensive practice and feedback. Critical thinking is a way of thinking about the subject, content or content, or any problem where the thinker improves the quality of his thinking by skillfully sorting out the ideas they get [14].

Creative thinking skills. The main function of education is to train individuals to have selfconfidence, have curiosity, creative and innovative abilities, and also be able to understand differences. Learning ways or methods to pay attention to students who have such characteristics 
are needed so that all students are brought to a point where they can think about the source of the problem and the solution. Creative thinking, a thinking skill, includes skills such as facilitating individual learning with the realization of their imagination, giving them opportunities to think, expressing ideas easily and getting them to get new information. To spread creative thinking in the school environment, the teaching and learning environment must be arranged in such a way that students can increase their creativity in that field. Thus, appropriate teaching methods, strategies and techniques should be used when achieving this [15]. It is important to note that the talented individuals who are present in every society in the number of $2-3 \%$ are trained according to their respective fields [16].

The term 'creativity' or 'creative thinking' is considered to refer to new insights, approaches, perspectives and ways of understanding and understanding something. The creative output includes several clear points such as poetry, dance, music, dramatic literature, and technical inventions and innovations. In addition, creative thinking can also be a way of asking questions that expand knowledge, find solutions to problems, or how to understand things from a different point of view [17]. Critical thinking and creative thinking will play an important role in preparing students to be able to solve a problem well, be able to make appropriate decisions and conclusions, and be able to take responsibility for them.

Analytical thinking skills. Analytical thinking skills include learning to determine pieces of information that are relevant or important (differentiating), determining ways to organize these pieces of information (organizing), and determining the purpose behind that information (attributing) [18]. Analytical thinking is a thought process that leads us to better decisions. First, it starts with creative thinking by weighing possible options for the problems we face, and then using analytical thinking processes to come up with better alternative solutions. Analytical thinking basics are used to encourage us to have alternative choices, and then gradually focus more on those choices [19].

Analytical thinking skills are needed when ambiguous situations occur, requiring students to identify and solve problems. Reasoning is a skill that is an important element for students to do problem solving and analytical thinking. That is, when the environment requires students to produce reasoning, then that is where the role of analytical thinking begins to appear [20]. Analytical thinking is the abstract separation of the whole into parts in order to study the parts and their relationships. Activities in analytical thinking are as follows: analyzing, arranging, connecting, dividing, separating, classifying, comparing, contrasting, explaining, choosing, sequence, details, correlation, diagram, discrimination, focus, discrimination, describing, concluding, outlining, prioritizing, divide and show [21].

\subsection{Learning Model Problem Based Learning (PBL)}

Problem-based learning (PBL) is an educational approach where a problem becomes the starting point of the learning process. Problems that arise are adapted to real life, then modified in such a way as to meet educational goals and criteria. Problems can also lead to hypotheses that are used as basic principles in the learning process. This is because these problems can determine the direction of the learning process and emphasize the formulation of questions rather than answers. This also allows the learning process to increase student motivation and understanding [22]. PBL is a pedagogical approach that allows students to learn while actively engaging with meaningful problems. Students are given the opportunity to solve problems in their environment, creative models in learning, and get used to independent learning through 
practical learning and reflection. Hence, the philosophy underlying PBL is that learning can be considered as "constructive, self directed, collaborative and contextual".

In the principle of constructivism, it positions students as information seekers who organize new experiences that are relevant to their daily lives or previous knowledge. In addition to enabling students to understand the subject matter and its concepts, this learning experience also tends to be able to help students develop an understanding of themselves, as well as the ways or situations that make them learn effectively. PBL as a pedagogical strategy of interest to many educators. This is because this method is able to offer an instructional framework that will support active and group learning processes, based on the belief that effective learning will be realized when students are able to build and continue to build ideas through social interaction and directed learning [23].

PBL is a learning approach that focuses on dissecting and discussing problems or cases in small groups which are usually supervised by one or more expert tutors or instructors [24]. Problem-based learning refers to unstructured problems that are messy and complex in nature, which in their solution require investigation, information gathering and reflection. Problembased learning is focused on hands-on learning that is organized based on investigating and solving real-world problems. Problem-based learning includes three main characteristics, namely: 1) making students stakeholders in problem situations / learning processes. 2) regulate the application of the curriculum around holistic issues, thus enabling the learning process of students in ways that are relevant and connected to one another; and 3) creating a learning environment that supports teachers to train students' thinking and guide student questions, and facilitates deeper levels of understanding [25].

\section{Methodology}

According to Ryan et al. (1992) in his book entitled Research Methodology in Finance and Accounting research is a process of intellectual discovery, which has the potential to change our knowledge and understanding of the world around us [26]. This study aims to analyze the students' ability in doing HOTS-based questions, especially in mathematics. HOTS-based learning is expected to improve student competence, especially in higher-order thinking skills, namely critical, creative, and analytical thinking skills.

\subsection{Sampling and Data Collection}

This research was conducted in 5 elementary schools in 5 clusters located in Girimarto District. The study was conducted with a total of 106 students with details of 53 male students and 53 female students. Data on the number of students in each primary school are as follows:

a. SD Negeri 1 Jatirejo totaling 20 students

b. SD Negeri 4 Girimarto as many as 23 students

c. SD Negeri 2 Bubakan totaling 28 students

d. SD Negeri 3 Gemawang as many as 15 students

e. SD Negeri 1 Waleng as many as 20 students

\subsection{Research Instruments}


Data collection was carried out through questionnaires, interviews, and tests. The test questions consisted of 5 questions which contained three components, namely critical, creative, and analytical. The indicators for each component are presented in Table 1.

Table 1. HOTS Based Learning Indicators

\begin{tabular}{|c|c|c|}
\hline Number & Component & Indicators \\
\hline \multirow{3}{*}{1} & \multirow{3}{*}{ Critical } & Able to formulate problem points. \\
\hline & & Be able to reveal the facts needed to solve a problem. \\
\hline & & $\begin{array}{l}\text { Able to prove right or wrong against something that has been } \\
\text { studied and concluded. }\end{array}$ \\
\hline \multirow{3}{*}{2} & \multirow{3}{*}{ Creative } & $\begin{array}{l}\text { Able to provide various interpretations of a picture, story or } \\
\text { problem. }\end{array}$ \\
\hline & & Able to detail an object so that it becomes interesting. \\
\hline & & Be able to find other ways of working on existing problems. \\
\hline \multirow{3}{*}{3} & \multirow{3}{*}{ Analytical } & $\begin{array}{l}\text { Be able to determine the pieces of information that are relevant } \\
\text { and important. }\end{array}$ \\
\hline & & $\begin{array}{l}\text { Be able to show the purpose and the relationship between the } \\
\text { pieces of information available. }\end{array}$ \\
\hline & & Able to organize available information elements. \\
\hline
\end{tabular}

\subsection{Data analysis}

This research was conducted to analyze the success of students in mathematics using HOTS-based learning. In this study, researchers conducted interviews, observed, distributed questionnaires, and provided test questions for students. The test questions were given before and after the application of HOTS-based learning.

\section{Results and Discussion}

\subsection{Results}

This study emphasizes the students' abilities in higher order thinking activities which consist of 3 components, namely critical, creative, and analytical. Students are said to be able to master HOTS-based learning if they have critical, creative, analytical thinking about information and data in solving problems. HOTS-based learning is expected to help teachers and students achieve learning goals and can improve student learning outcomes in mathematics.

Research conducted by Fanani and Kusmaharti (2018) [27] entitled "Development of HOTS (Higher Order Thinking Skill) Based Learning in Class V Elementary Schools" shows that learning development is able to produce total learning outcomes (91\%) in learning. This proves that HOTS-based learning can significantly improve learning outcomes.

Another study also conducted by Chabeli (2006), entitled "Higher Order Thinking Skills Competencies Required by Outcomes-Based Education from Learners" shows that thinking skills are needed to improve learning outcomes because the results will later be used while in the world of work. The competencies and skills that are owned can be a provision for lifelong 
learning. Both teachers and students will be faced with challenges in the future so that this competency will be very useful for life [28].

Hugerat \& Kortam (2014) in their research entitled "Improving Higher Order Thinking Skills among freshmen by Teaching Science through Inquiry" said that the learning method had a significant influence on HOTS development. There was an increase in the pre-test and posttest which showed the effect of the application of learning methods [29].

Based on previous research, HOTS-based learning can affect learning outcomes. Based on the observations that have been made in this study, the use of students' higher thinking skills is still lacking so that it affects the low learning outcomes. Students still need guidance from the teacher to improve their thinking skills because this competency will be a provision in the future to deal with various problems that occur.

Table 2. Student Learning Outcomes Before Implementing HOTS Based Learning

\begin{tabular}{llc}
\hline Number & Component & Yield Percentage (\%) \\
\hline 1. & Critical & 46,86 \\
\hline 2. & Creative & 37,50 \\
\hline 3. & Analytical & 30,82 \\
\hline Rata-rata & & 37,61 \\
\hline
\end{tabular}

Based on the data from the table above, it can be seen that the average of the three components in HOTS is still in the low category. As much as $46.86 \%$ of students mastered the critical thinking component (see the blue part), $37.50 \%$ of students mastered the creative thinking component (see the red part), and only $30.82 \%$ of students could mastered the analytical thinking component (see the grey part). The average of these three components is $37.61 \%$. The diagram of the three components can be seen in Figure 1.

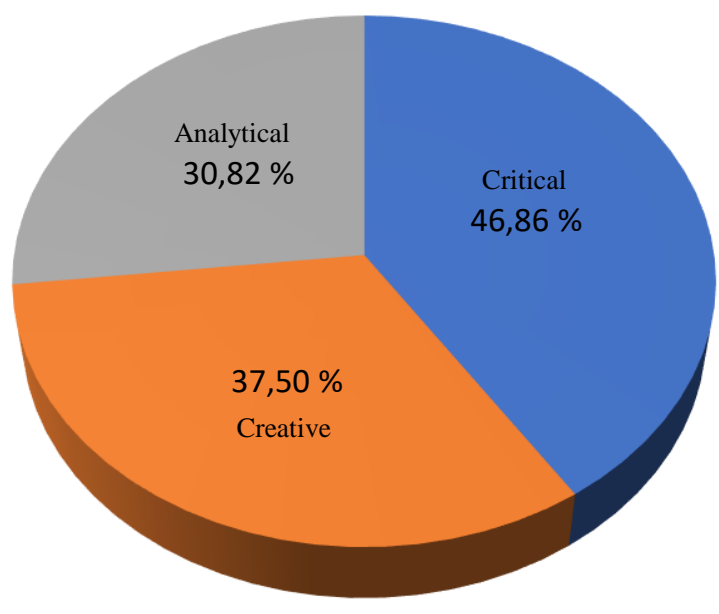

Fig. 1. Percentage of Student Learning Outcomes

The low student learning outcomes can be seen in the diagram above. Therefore it is necessary to modify the learning activities so that student learning outcomes can be maximized and achieve the best results. Researchers hope that the implementation of HOTS-based learning 
in teaching and learning activities can have a good impact on student learning outcomes. HOTS learning emphasizes critical, creative, and analytical components, which in addition to improving student learning outcomes can also be used as provisions for students to face the future.

\subsection{Discussion}

Based on the results of observations, interviews, and tests conducted, out of 106 male and female students, $46.86 \%$ of students mastered the critical thinking component, $37.50 \%$ of the students mastered the creative thinking component, and only $30.82 \%$. students who can master analytical thinking. The average of these three components is $37.61 \%$. This shows that students' high-order thinking skills are still low. Based on the research results, it can be seen that most of the male students who get low scores on the three HOTS components. Based on research conducted by Lim and Morris (2009), it shows that age, previous experience, the teacher's delivery format, and the student's average learning time are some of the factors that differentiate student learning outcomes [30].

In a study conducted by Stanley, he said that the bloom taxonomy has the highest 3 levels in learning activities, namely analysis, synthesis, and evaluation, all of which are Higher Order Thinking Skills. If students want to learn how to think critically and intelligently, then they must be equipped with proper teaching. Schools still rarely apply HOTS-based learning. Even though they have started to do so, their implementation is still not effective [31].

This condition is still common in various elementary schools in Girimarto District. The school still applies ordinary learning that has not implemented HOTS-based learning. Thus, many students also experience difficulties when faced with questions that require students to think critically, creatively, and analytically. HOTS learning can not only improve higher order thinking skills but also can help students to improve learning outcomes. Thus it will help students at the next level of education. Teachers in Girimarto Subdistrict still do not understand the HOTS-based learning concept so they have difficulty making learning designs that can improve students' thinking skills. Some things that can be done are providing trainings for teachers to design learning that can improve students' thinking skills, besides that learning is fun so that student interest in learning activities is high. One learning model that can improve students' HOTS skills is the Problem Based Learning (PBL) learning model.

\section{Conclusion and Recommendation}

\subsection{Conclusion}

Student learning outcomes in learning are still in the poor category, therefore the use of HOTS-based learning. HOTS-based learning provides concrete examples of how teachers should design lessons that can improve higher-order thinking skills which include critical thinking, creative thinking, and analytical thinking. This learning can train students' thinking skills to find various alternative solutions to problem solving, think deeply, and be able to describe the information obtained. At school, students get a little HOTS-based learning. When questions or materials concerning HOTS arise, students have difficulty identifying them. Teachers are still lacking in supporting the line of reasoning to draw conclusions or explain their judgments. Teachers and students need to work together in carrying out HOTS-based learning 
activities to improve student learning outcomes. This can be done by applying the Problem Based Learning (PBL) model to improve students' higher order thinking skills.

\subsection{Recommendation}

This study recommends schools in Girimarto District to apply the Problem Based Learning (PBL) learning model to improve students' higher order thinking skills. Due to the low ability of students to solve HOTS-based questions, it is necessary to have a learning design that can train students' thinking skills. In this regard, the Education Office in Central Java also needs to facilitate training for teachers to apply learning models that can improve student learning outcomes as well as students' higher order thinking skills. In addition, students need to be given the understanding that learning outcomes and thinking skills are very important for students because they will be used by students as provisions for the next level of education and in the future.

\section{References}

[1] Ariyana, Y., dkk.. Buku Pegangan Pembelajaran Berorientasi pada Keterampilan Berpikir Tingkat Tinggi. Jakarta : Kementerian Pendidikan dan Kebudayaan; 2018 : pp. 2.

[2] Chinedu, C.C. dan Kamin Y. Strategies for Improving Higher Order Thinking Skills in Teaching and Learning Of Design and Technology Education. Journal of Technical Education and Training (JTET). 2015; 7(2): pp. 35-43.

[3] Hoque, M. E.. Three Domains of Learning: Cognitive, Affective and Psychomotor. The Journal of EFL Education and Research (JEFLER). 2016; 2(2): pp. 45-52.

[4] Tam, N.T.M.. Using Problem-Based Learning To Promote Students' Use of Higher-Order Thinking Skills and Facilitate Their Learning. VNU Journal of Foreign Studies. 2018; 34(2): 90-110.

[5] Tremblay, K.. Assessment of Higher Education Learning Outcomes. Feasibility Study Report. 2012; 1: pp. 9.

[6] Gagné, R. M.. Learning outcomes and their effects: Useful categories of human performance. American Psychologist. 1984; 39(4): pp. 377-385.

[7] Prentice, M. dan Robinson, G.. Improving Student Learning Outcomes with Service Learning. Higher Education. 2010: Paper 148.

[8] Liu, O.L., dkk.. Measuring Learning Outcomes in Higher Education: Motivation Matters. Educational Researcher. 2012; 41(9): pp. 352-362.

[9] Jordan, R.C., dkk.. Key issues and new approaches for evaluating citizen-science learning outcomes. The Ecological Society of America. 2012; 10(6): pp. 307-309.

[10] Forster, M., dkk. Resource Handbook on Performance Assessment and Measurement. Berkeley, CA: The Owl Press; 1993: pp. 11.

[11] Ennis, R. H.. Critical thinking assessment. Collage of Education. 1996: 32(3): pp. 179-186.

[12] Moon, J.. Critical Thinking an Explanation of Theory and Practice. USA : Routledge; 2008: pp. 20.

[13] Paul, R.W.. Critical Thinking: What Every Person Needs to Survive in a Rapidly Changing World. CA : Sonoma State University. 1990; pp. 1-25.

[14] Fisher, A.. Critical Thinking an Introduction Second edition. UK : Cambridge University Press; 2011: pp. 1-293.

[15] Ersoy, E. dan Başer N.. The effects of problem-based learning method in higher education on creative thinking. Academic World Education and Research Center. 2014; 116: pp. 3494 - 3498.

[16] Çetinkaya, Ç. The effect of gifted students' creative problem solving program on creative thinking. Academic World Education and Research Center. 2014; 116: pp. 3722 - 3726.

[17] Eragamreddy, N.. Teaching Creative Thinking Skills. IJ-ELTS: International Journal of English Language \& Translation Studies. 2013; 1(2): pp. 124-145. 
[18] Anderson, L.W dan Krathwohl, D.R. Kerangka Landasan untuk Pembelajaran, Pengajaran dan Asesmen (Revisi Taksonomi Pendidikan Bloom). Yogyakarta: Pustaka Pelajar; 2010.

[19] Nuroso H., dkk.. Developing a Learning Model to Promote the Skills of Analytical Thinking. Journal of Education and Learning (EduLearn). 2018; 12(4): pp. 775-780.

[20] Robbins, J.K.. Problem Solving, Reasoning, and Analytical Thinking in a Classroom Environment. Morningside Academy and Partnerships for Educational Excellence and Research. 2011; 12(1): pp. 41-48.

[21] Montaku, S.. Results of analytical thinking skills training through students in system analysis and design course. IETEC'11 Conference. 2011: pp. 1-13.

[22] Graaff, E.D. and Kolmos A.. Characteristics of Problem-Based Learning. International Journal of Engineering. 2003; 19(5): pp. 657-662.

[23] Yew, E.H.J. and Goh K... Problem-Based Learning: An Overview of its Process and Impact on Learning. Health Professions Education. 2016; 2: pp. 75-79.

[24] Chang, B. J. Problem-based learning in medical school: A student's perspective. IJS Publishing Group. 2016: 12: pp. 88-89.

[25] Akçay, B. Problem-Based Learning in Science Education. Journal of Turkish Science Education. 2009; 6(1): pp. 26-36

[26] Ryan, B. dkk.. Research Method and Methodology in Finance and Accounting. UK:Academic Press Limited. 1992: pp. 7.

[27] Fanani, A. dan Kusmaharti D.. Pengembangan Pembelajaran Berbasis HOTS (Higher Order Thinking Skill) di Sekolah Dasar Kelas V. JPD: Jurnal Pendidikan Dasar. 2018: pp. 1.

[28] Chabeli, M.M. Higher Order Thinking Skills Competencies Required By Outcomes-Based Education From Learners. Research Article. 2006: pp. 78.

[29] Hugerat, M. and Kortam N.. Improving Higher Order Thinking Skills among freshmen by Teaching Science through Inquiry. Eurasia Journal of Mathematics, Science \& Technology Education. 2014; 10(5): pp. 447-454.

[30] Lim, D.H. dan Morris, M.L. Learner and Instructional Factors Influencing Learning Outcomes within a Blended Learning Environment. Educational Technology \& Society. 2009; 12(4): pp. 282-293.

[31] Ivie, S.D. Ausubel's Learning Theory: An Approach to Teaching Higher Order Thinking Skills. The High School Journal. 1998; 82(1): pp. 35-42. 